Jurnal BASTRA (Bahasa dan Sastra) : http://ojs.uho.ac.id/index.php/BASTRA

\title{
HUMANISME DALAM ANTROLOGI PUISI "BUTON, IBU DAN SEKANTONG LUKA" KARYA IRIANTO IBRAHIM
}

\author{
OLEH \\ M. Syamsul Mubarak', Amirudin Rahim² dan La Ode Sahidin ${ }^{3}$ \\ ${ }^{1}$ Alumni Jurusan Pend. Bahasa dan Sastra Indonesia, ${ }^{2,3}$ Dosen Jurusan Pendidikan \\ Bahasa dan Sastra Indonesia, Fakultas Keguruan dan Ilmu Pendidikan \\ Universitas Halu Oleo
}

\begin{abstract}
ABSTRAK
Penelitian ini bertujuan untuk mendeskripsikan konsep humanisme yang tertuang dalam makna puisi-puisi Irianto Ibrahim dengan menggunakan metode deskriptif kualitatif. Metode deskriptif mengandung pengertian bahwa penelitian ini menguraikan data secara objektif sesuai dengan data yang ditemukan dalam puisi. Sementara itu, kualitatif mengandung pengertian bahwa dalam menjelaskan konsepkonsep yang berkaitan satu sama lain digunakan kata-kata atau kalimat, bukan mengandung angka-angka statistik.

Hasil penelitian ini menunjukkan bahwa pemaknaan keenam puisi Irianto Ibrahim menuju pada eksistensi manusia dalam kehidupan yang biasa dipahamai sebagai konsep manusia (humanisme) universal dan mengandung tiga pokok penting yakni: (1) eksistensi manusia sebagai makhluk spiritual (puisi Buton 1969, Bunda, Kirimkan Nanda Doa-Doa, dan Alamat Maut), (2) eksistensi manusia dalam sikap toleransi antar manusia sebagai aktifitas dan interaksi sosial (puisi Buton 1969, Sekantong Luka dari Seorang Ibu, Ibuku Tak Pernah Menangis dan Jalan Pulang), (3) manusia yang berhubungan dengan sikap keindividualannya (puisi Bunda, Kirimkan Nanda Doa-Doa).

Jika diamati secara saksama melalui contoh-contoh puisi yang telah dikemukakan di bagian sebelumnya, terdapat tiga wilayah penting kehidupan manusia yang selalu ditimba oleh para penyair sebagai sumber penciptaan puisipuisinya, yakni wilayah kehidupan individual, kehidupan sosial, dan kehidupan agama. Dengan kata lain, puisi akan selalu berkenaan dengan masalah manusia dalam hubungannya dengan diri sendiri, dalam hubungannya dengan manusia lain atau alam, dan dalam hubungannya dengan Tuhan.
\end{abstract}

Kata Kunci: humanisme, antrologi, puisi

33 | Jurnal BASTRA (Bahasa dan Sastra), Vol. 4 No.1, Edisi Januari 2019/e-ISSN: 2503-3875/ http://ojs.uho.ac.id/index.php/BASTRA 


\section{PENDAHULUAN}

\subsection{Latar Belakang}

Sastra lahir sebagai gambaran kehidupan manusia. Dengan kata lain, sastra selalu berhubungan antara manusia dengan manusia, manusia dengan alam atau lingkungan, atau manusia dengan Tuhannya. Sebagai gambaran kehidupan manusia, semua hubungan tersebut bersifat dinamis. Menyikapi salah satu sifat sastra yang berhubungan dengan kehidupan manusia baik sebagai gambaran kehidupan maupun tiruan kenyataan, maka dikenal ilmu humanisme yang dasarnya merupakan ilmu yang mengkaji sebuah karya sastra dari sisi rasa kemanusiaan. Dalam konsep humanisme tindakan kodrat menjadi ukuran sehingga pikiran, rasa, situasi seluruhnya akan ikut menentukan baik buruknya tindakan konkret manusia. Memahami lebih jauh tentang konsep humanisme, kita akan menemukan adanya hubungan sosial antara seorang manusia dengan lingkungannya, entah itu berupa manusia dengan individu, dengan kelompok dan dengan alamnya.

Dapat diartikan secara khusus bahwa humanisme mencakup banyak lingkup sosial yang bisa berupa keinginan atau mencita-citakan adanya kebebasan dari penindasan, kesempurnaan hidup, keadilan, kebenaran, kesadaran diri manusia, mendahulukan masyarakat atas individu, penolakan atas kesewenangwenangan, menolak perang, melindungi peribadatan, menolak kebodohan dan kelemahan, kemampuan memperjuangkan hak hidup yang bersifat universal, menolak diskriminasi individu dan golongan serta previlage social. Inilah cita-cita humanisme sepanjang sejarah menurut Syari'ati, manusia yang beradab dari kaum intelektual yang bebas dan cinta kemanusiaan.

Secara umum pemaknaan puisi karya penyair Irianto Ibrahim berfokus pada antologi puisi yang ia tulis, yang didasari pada otoritas pemaknaan terhadap teks memberi gambaran terhadap sosok si pengarang yang akan melibatkan perenungan dalam sudut pandang ego personal, spirit religius, manusia dalam hakikatnya sebagai makhluk ciptaan Tuhan, penyair dalam sajaknya, dan hubungan toleransi beragama sebagai aktifitas dan interaksi soasial. Oleh karena itu, perbedaan sudut pandang sosok si pengarang inilah yang menjadi suatu perhatian dalam penelitian ini.

Diketahui, antologi merupakan sebuah buku kumpulan puisi dari seorang atau beberapa penulis yang diterbitkan oleh percetakan. Dalam sebuah antologi tunggal hanya terdapat seorang penulis saja. "Buton, Ibu dan Sekantong Luka" karya Irianto Ibrahim merupakan sebuah antologi tunggal terbitan Frame publishing, tahun 2010 silam dan berisi 53 buah sajak karya Irianto Ibrahim yang ditulis sejak tahun 2001 hingga tahun diterbitkannya antologi tersebut. Pemilihan antologi didasari oleh kebebasan memilih sajak yang erat kaitannya dengan penelitian, dalam hal ini yakni humanisme.

Ada beberapa buah puisi yang menjadi objek penelitian humanisme dalam antologi puisi "Buton, Ibu dan Sekantong Luka" yaitu Buton 1969, Sekantong Luka Dari Seorang Ibu, Bunda Kirimkan Nanda Doa-doa, Jalan Pulang, Ibuku tak Pernah Menangis, Alamat Maut, dan Buton. Pemilihan puisi tersebut berdasarkan pada pertimbangan makna yang mengandung fakta sejarah, dan makna 
yang mengandung kekuatan teks. Puisi terpilih juga merupakan representatif dari keseluruhan antologi puisi, dengan kata lain, ke enam puisi tersebut secara garis besar menjadi perwakilan-perwakilan dari keseluruhan puisi pada antologi tersebut.

\subsection{Rumusan Masalah}

Pemaparan latar belakang yang telah dikemukakan sebelumnya merupakan dasar dari penelitian ini. Sehubungan dengan hal tersebut, maka permasalahan dalam penelitian ini adalah "aspek humanisme apa saja yang terdapat pada sajak-sajak yang terpilih dalam antologi puisi Buton, Ibu dan Sekantong Luka karya Irianto Ibrahim dengan menggunakan pendekatan hermeneutic"?

\subsection{Tujuan Penelitian}

Berdasarkan masalah tersebut, maka penelitian ini bertujuan untuk mendeskripsikan aspek humanisme apa saja yang terdapat pada sajaksajak terpilih dalam antologi puisi "Buton, Ibu dan Sekantong Luka" karya Irianto Ibrahim dengan menggunakan pendekatan hermeunetik untuk memaknai puisinya.

\subsection{Manfaat Penelitian}

Penelitian dilakukan tentunya akan membawa suatu manfaat, baik itu bagi pembacanya maupun bagi peneliti itu sendiri. Manfaat penelitian dapat bersifat keilmuan dan kepraktisan. Dengan kata lain, hasil penelitian dapat bermanfaat untuk mengembangkan ilmu dan dapat pula diterapkan dalam kehidupan seharihari. Berkaitan dengan hal itu dan hubungannya dengan tujuan yang telah dipaparkan sebelumnya maka manfaat penelitian ini antara lain:

1. Melalui penelitian ini, penulis diharapkan mampu mendeskripsikan aspek-aspek humanisme apa saja yang terdapat pada sajak-sajak terpilih dalam antologi puisi "Buton, Ibu dan Sekantong Luka" karya Irianto Ibrahim. Selain itu, juga dapat menambah khazana pengetahuan dan pemahaman penulis terhadap analisis puisi untuk memahami makna yang terkandung dalam puisi.

2. Melalui penelitian ini diharapkan dapat bermanfaat sebagai bahan studi perbandingan dalam upaya penelitian selanjutnya yang dianggap relevan..

3. Melalui penelitian ini diharapkan dapat memberi bahan informasi mengenai analisis puisi dalam sudut pandang humanisme. Informasi tersebut kemudian diharapkan dapat memunculkan metode dan startegi yang efektif serta efisien dalam penelitian yang berhubungan dengan memahami makna yang terkandung dalam suatu puisi terkhusus analisis tentang humanisme dalam pemaknaan puisi.

\subsection{Batasan Operasional}

Untuk menghindari kesalahan penafsiran mengenai istilah yang digunakan dalam penelitian ini, maka diuraikan beberapa istilah sebagai berikut:

1. Puisi merupakan karya imajinatif penyair yang bersifat simbolis dengan menggunakan bahasa yang mengacu kepada realitas lain selain realita awalnya yang dibentuk melalui kata-kata sebagai aktifitas tanda dan melibatkan 
pembaca dengan tindakantindakan pembacaannya sendiri.

2. Humanisme adalah suatu pemahaman dimana eksistensi manusia merupakan unsur sentral dalam pembahasannya.

3. Antologi merupakan kumpulan karya tulis pilihan dari seseorang atau beberapa orang.

\section{KAJIAN PUSTAKA}

\subsection{Pengertian Sastra}

Sastra memiliki berbagai pengertian seiring dengan teori yang dibawanya. Teori sastra diartikan sebagai sebuah perangkat ide-ide dan metode yang digunakan untuk praktik pembacaan sastra karena pada hakikatnya sastra merupakan suatu karya yang dihadirkan berdasarkan pengalaman-pengalaman yang ada dalam realitas kehidupan. Pada zaman dahulu, seni dalam pandangan Plato adalah mimesis atau meniru alam. Pandangan plato tersebut kemudian ditentang muridnya, yakni Aristoteles. Menurutnya seni atau sastra haruslah dapat menyucikan jiwa. Seni bukan sajati ruang alam melainkan ciptaan kedua. Aristoteles juga menolak pandangan Plato mengenai mimesis. Menurutnya mimesis akan menimbulkan unsur positif pada penciptaan seni (sastra sebagai karya seni) yang tidak lain adalah perpaduan antar unsur-unsur yang ada dan melakukan pencerahan pada aspek ideal.

Mengacu pada pernyataan di atas, dapat disimpulkan bahwa dalam karya sastra pada kenyataannya akan melibatkan beberapa unsur yakni pengarang sebagai pihak yang menghadirkan karya, karya yang bersifat imajinaf dengan bahasa sebagai sarana untuk mengungkapkan realitas dan publik (pembaca) yang juga terikat pada karya untuk memahami karya yang dibentuk melalui teks yang terbahasakan.

\subsection{Pengertian Puisi}

Puisi adalah karya sastra dengan bahasa yang dipadatkan, dipersingkat, dan diberi irama dengan bunyi yang padu dan pemilihan kata-kata kias (imajinatif). Kata-kata betul-betul terpilih agar memiliki kekuatan pengucapan. Walaupun singkat atau padat, namun berkekuatan. Kata-kata itu mewakili makna yang lebih luas dan lebih banyak. Karna itu, kata-kata dicarikan konotasi atau makna tambahannya dan dibuat bergaya dengan bahasa figurative. Dalam puisi kata-kata tidaklah keluar dari simpanan ingatan, kata-kata dalam puisi itu lahir dan dilahirkan kembali (dibentuk) pada waktu pengucapannya sendiri. Dalam puisi tak ada perbedaan kata dengan pikiran. Pikiran itu adalah kata itu sendiri dan kata adalah pikiran itu sendiri (kata dan pikiran itu adalah puisi).

Waluyo (dalam Kosasih, 2012: 97) menyatakan bahwa secara garis besar, unsur-unsur puisi terbagi kedalam dua macam, yakni struktur fisik dan struktur batin.

\subsubsection{Unsur Fisik}

Bentuk dan struktur fisik puisi sering di sebut metode puisi. Sengaja tidak digunakan istilah metode puisi supaya tidak kacau dengan bidang lain misalnya bidang penelitian (Siswanto, 2008:113). Unsur fisik meliputi halhal sebagai berikut:

a. Diksi (Pemilihan Kata)

Kata-kata yang digunakan dalam puisi merupakan hasil pemilihan yang sangat cermat.

\subsubsection{Pengimajinasian}


Pengimajinasian adalah kata atau susunan kata yang dapat menimbulkan khayalan atau imajinasi.Dengan daya imajinasi tersebut, pembaca seolah-olah merasa, mendengar, atau melihat sesuatu yang diungkapkan penyair. Dengan katakata yang digunakan penyair, pembaca seolah-olah

a. Mendengar suara (imajinasi auditif)

b. Melihat benda-benda (imajinasi visual), atau

c. Meraba dan menyentuh bendabenda (imajinasi taktil).

2.2.1.2 Bahasa figurative (Majas)

Majas (figurative leaguage)

ialah bahasa yang digunakan penyair untuk mengatakan sesuatu dengan cara membandingkan dengan benda atau kata lain. Majas mengiaskan atau mempersamakan sesuatu dengan yang lain. Maksudnya, agar gambaran benda yang dibandingkan itu lebih jelas.

\subsubsection{Unsur Batin}

Struktur batin puisi ada empat unsur yaitu:

\subsubsection{Tema atau Makna}

Tema merupakan gagasan pokok yang diungkapkan penyair dalam puisinya.Tema berfungsi sebagai landasan utama penyair dalam puisinya.Tema itulah yang menjadi kerangka pengembangan sebuah puisi. Jika landasan awalnya tentang ketuhanan, maka keseluruhan struktur puisi itu tidak lepas dari ungkapanungkapan atas eksistensi Tuhan. Demikian halnya jika yang dominan adalah dorongan cinta dan kasih sayng, maka yang ungkapanungkapan asmaralah yang akan lahir dalam puisi itu.

2.2.2.2 Perasaan

Puisi merupakan karya sastra yang paling mewakili ekspresi perasaan penyair. Bentuk ekspresi itu dapat berupa kerinduan, kegelisahan, atau pengagungan kepada kekasih, kepada alam, atau sang Khalik.

Jika penyair hendak mengagungkan keindahan alam, maka sebagai sarana ekspresinya ia akan memanfaatkan majas serta diksi yang mewakili dan memancarkan makna keindahan alam. Jika ekspresinya merupakan kegelisahan dan kerinduan kepada sang Khalik, maka bahasa yang digunakannya cenderung bersifat perenungan akan eksistensinya dan hakikat keberadaan dirinya sebagai hamba Tuhan.

2.2.2.3 Amanat atau Tujuan

Kosasih (2012:

berpendapat bahwa tujuan/amanat merupakan hal yang mendorong penyair untuk menciptakan puisinya. Amanat tersirat dibalik kata-kata yang disusun, dan juga berada dibalik tema yang diungkapkan. Amanat yang hendak disampaikan oleh penyair mungkin secara sadar berada dalam pikiran penyair, namun lebih banyak penyair tidak sadar akan amanat yang diberikan.

\subsection{Pengertian Hermeneutik}

Manusia hidup di tengah berjuta tanda dengan segala bentuk, nilai, dan maknanya. Ada kalanya, mereka mengerti secara refleks arti sebuah tanda, sedangkan lainnya perlu melakukan analisis mendalam untuk mendapatkan makna yang diharapkan. Kehadiran semiotika, atau semiology dalam istilah Barthes, membuka jalan pintas untuk memahami makna yang terkandung dalam suatu petanda beserta sistem, aturan, dan konvensi yang memungkinkan petanda itu memiliki makna.

Richard E. Palmer (2016: 3-4) menyatakan hermeneutika adalah kata yang sering digunakan dalam bidang 
toelogi, filsafat, bahkan sastra. Dengan adanya klaim-klaim kontemporer menyangkut signifikasi hermeneutika dalam tiga disiplin ilmu humanistic ini-teologi, filsafat, dan interpretasi sastra- menjadi lebih jelas bahwa kajian ini akan mempertimbangkan pentingnya bagi pelopor-pelopor pemikiran Amerika dalam beberapa tahun yang akan datang. Namun sesungguhnya istilah hermeneutika ini bukanlah sebuah kata baku, baik dalam filsafat maupun penelitian sastra; dan bahakan dalam bidang teologi penggunaan term ini sering kali muncul dalam makna yang sempit yang berbeda dengan penggunaan secara luas "Hermeneutik Baru" teologis kontemporer.

Menurut Ricoeur (Mulyono, 2012:256-264), tugas utama hermeneutika adalah untuk memahami teks. Oleh karena itu, pengertian tentang teks menjadi sangat sentral dalam pemikiran hermeneutika Ricoeur. Secara mendasar, Ricoeur mengatakan bahwa teks adalah "any discourse fixed by writing." Dengan istilah discourse merujuk kepada Bahasa sebagai event, yaitu bahasa yang membicarakan sesuatu. Penjelasan lebih lanjut Ricoeur terhadap konsep teks ini juga akan menjadi revisi bagi konsep Dilthey tentang explanation dan understanding. Dithey menganggap bahwa penjelasan aadalah kararakteristik kerja ilmu alam, yaitu mengungkapkan cara kerja fenomena alami yang pasti dan tanpa intensi. Sementara pemahaman adalah cara kerja ilmu humaniora, untuk mengungkapkan prilaku manusia yang sangat kompleks, tidak kausalistik, dan memiliki intensionalitas. Sedangkan menurut Ricoeur, kedua cara kerja metodologis tidak bias dipisahkan secara dikotomis. Dengan menerapkan pada persoalan hubungan anatara metafor dan teks sebagai kodifikasi bahasa lisan dan bahasa tulis, Ricoeur menunjukkan bagaimana penjelasan dan pemahaman dapat diterapkan pada sisi yang berlainan. Penjelasan (explanation) adalah cara kerja yang menghubungkan metafor kepada teks, yaitu pembakuan Bahasa lisan kepada Bahasa tulis, sementara interpretasi (interpretation) adalah cara kerja dari teks ke metafor, yaitu taranskripsi dari bahasa tulis ke bahasa lisan.

Dengan demikian, jika mengibaratkan puisi adalah buah, maka untuk megetahui apa yang terdapat dalam buah itu, baik warna, tekstur dan tingkat kematangannya, hermeneutic merupakan sebuah alat yang akan mengupas keseluruhan kulit buah. Dengan kata lain, pembedahan puisi untuk mengetahui makna dan pesan di dalamnya, dalam penelitian ini akan menggunakan pendekatan hermeneutic.

\section{METODE DAN TEKNIK PENELITIAN}

\subsection{Metode Penelitian}

Metode yang di gunakan dalam penelitian ini adalah metode deskriptif kualitatif. Metode deskriptif mengandung pengertian bahwa penelitian ini menguraikan data secara objektif sesuai dengan data yang ditemukan dalam puisi. Sementara itu, kualitatif mengandung pengertian bahwa dalam menjelaskan konsepkonsep yang berkaitan satu sama lain digunakan kata-kata atau kalimat, bukan mengandung angka-angka statistik. Jadi metode deskriptif kualitatif adalah metode yang digunakan untuk menguraikan data 
secara objektif dengan menggunakan kata-kata atau kalimat.

Ciri-ciri terpenting metode deskipsi kualitatif menurut Ratna, (2008:47-48) adalah sebagai berikut.

1. Memberikan perhatian utama pada makna dan pesan sesuai dengan hakikat objek, yaitu sebagai studi kultural.

2. Lebih mengutamakan proses dibandingkan dengan hasil penelitian sehingga makna selalu berubah.

3. Tidak ada jarak antara subjek peneliti dengan objek penelitian, subjek peneliti sebagai instrument utama, sehingga terjadi interaksi langsung di antaranya.

4. Desain dan kerangka penelitian bersifat sementara sebab penelitian bersifat terbuka.

5. Penelitian bersifat alamiah, terjadi dalam konteks sosialbudayanya masing-masing.

\subsection{Jenis Penelitian}

Penelitian ini merupakan penelitian kepustakaan (library research) yang bersifat kulitatif. Dikatkan penelitian kepustkaan karena penelitian ini didukung oleh referensi yang baik yang berupa teks puisi maupun sumber buku penunjang. Kepustakaan dapat berupa buku, jurnal, majalah, surat kabar, internet, dan beberapa tulisan yang memiliki relevansi dengan pembahasan dalam penelitian ini.

\subsection{Data dan Sumber Data}

\subsubsection{Data}

Data dalam penelitian ini adalah data tertulis berupa beberapa puisi yang terdapat dalam sebuah buku antologi puisi berjudul "Buton, Ibu dan Sekantong Luka” yaitu Buton 1969, Sekantong Luka Dari Seorang Ibu, Bunda Kirimkan Nanda Doa-doa, Jalan Pulang, Ibuku tak Pernah
Menangis, Alamat Maut, dan Buton. Pemilihan puisi berdasarkan pertimbangan sebagai berikut:

1. Puisi yang terpilih merupakan representatif dari keseluruhan antologi puisi, dalam hal ini, ke enam puisi tersebut secara garis besar merupakan perwakilan dari keseluruhan puisi.

2. Makna puisi yang terpilih. Hal ini bias terjadi karena puisi-puisi yang terpilih terdapat makna-makna yang kuat dalam kaitannya dengan fakta sejarah, maupun teksnya.

3. Puisi-puisi yang terpilih merupakan ikon dari antologi puisi.

\subsubsection{Sumber Data}

Sumber data dalam penelitian ini berupa sumber data primer yaitu adalah antologi puisi "Buton, Ibu dan Sekantong Luka" karya Irianto Ibrahim. Sumber data sekunder berupa artikel-artikel, jurnal-jurnal, dan kutipan-kutipan dari buku-buku teori yang mendukung penelitian.

\subsection{Teknik Analisis Data}

\subsubsection{Tahap Pengumpulan Data}

Sumber data dalam penelitian kualitatif terdiri dari beragam jenis, menuntut cara atau teknik pengumpulan data tertentu yang sesuai guna mendapatkan data yang diperlukan untuk menjawab permasalahannya. Strategi pengumpulan data dalam penelitian kualitatif secara umum dapat dikelompokkan kedalam dua cara, yaitu metode atau teknik pengumpulan data yang bersifat interaktif dan noninteraktif.

Pengumpulan data dilakukan dengan menggunakan metode noninteraktif, yaitu mengkaji dokumen dan arsip. Teknik studi pustaka digunakan untuk 
mengumpulkan data-data berupa buku-buku kepustakaan yang berkaitan dengan masalah penelitian.

\subsubsection{Tahap Pengolahan Data}

Menyoal tentang pengolahan data, selama analisis dalam rentang waktu pengumpulan dan pengolahan data, peneliti bergerak maju dan mundur di antara menelaah dan yang telah di peroleh data baru yang lebih berkualitas. Bogdan dan Bikle menyebutkan ada tiga langkah pengolahan data kualitatif, yakni reduksi data (data reduction), penyajian data (data display), dan penarikan kesimpulan (conclusion drawing and verification). Dalam pelaksanaannya reduksi data, penyajian data, dan penarikan kesimpulan/verifikasi, merupakan sebuah langkah yang sangat luwes, dalam arti tidak terikat oleh batasan kronologis. Secara keseluruhan langkah-langkah tersebut saling berhubungan selama dan sesudah pengumpulan data, sehingga model dari Miles dan Huberman disebut juga sebagai Model Interektif.

\subsubsection{Tahap Analisis Data}

Siswantoro (2016: 81), setelah merampungkan serangkaian kegiatan yang terkait dengan pengumpulan data, seperti reduksi data, penarikan kesimpulan, serta pengabsahan data, kegiatan selanjutnya adalah analisis. Analisis dilakukan dengan pemaparan dalam bentuk deskriptif terhadap masing-masing data secara fungsional dan relasional. Istilah analisis dalam format paparan, oleh Miles dan Huberman (1984) disebut sebagai data display.

Analisis data dalam penelitian ini menggunakan metode hermeneutik. Hermeneutika berasal dari kata Yunani hermeneuine dan hermeneia yang masing-masing berarti "menafsirkan" dan "penafsiran". Penelitian ini menggunakan metode hermeneutic karena penelitian ini bertujuan untuk mencari makna dari simbol-simbol dalam teks, yaitu makna puisi yang telah dipilih.

Kegiatan hermeneutic selalu bersifat triadik, menyangkut tiga subjek yang saling berhubungan. Tiga subjek yang dimaksud meliputi : the world of the text (dunia teks), the world oh the author (dunia pengarang) dan the world of the reader (dunia pembaca) yang masingmasing memiliki titik pusaran tersendiri dan saling mendukung dalam memahami sebuah teks.

Dengan demikian, langkahlangkah analisis data yang akan di gunakan dengan menggunakan pendekatan hermeneutic

a) Mula-mula teks puisi ditempatkan sebagai objek yang diteliti sekaligus sebagai subjek atau pusat yang otonom. Karya seni diposisikan sebagai fakta ontology.

b) Pada tahap berikutnya, pemahaman semakin meluas ketika masuk pada lapis teks. Hal ini terjadi sebab di sini tafsir telah melampaui batas struktur.

c) Kemudian teks puisi dikaitkan dengan berbagai persoalan di luar dirinya menuntut disiplin ilmu lain untuk melengkapi tafsir.

d) Akhirnya, ujung dari proses itu adalah ditemukannya makna atau pesan.

Dari skema di atas tampak bahwa makna dan pesan dalam tafsir hermeneutic berada pada wilayah yang paling luas dan paling berjauhan dengan teks (puisi sebagai fakta 
ontologisnya), tetapi tetap berada di dalam horizon yang dipancarkan teks.

\section{HASIL DAN PEMBAHASAN}

Bab ini merupakan analisis hasil penelitian terhadap enam puisi terpilih dalam antologi puisi "Buton, Ibu dan Sekantong Luka" karya penyair Irianto Ibrahim. Adapun puisi yang dimaksud yaitu (1) Buton 1969, (2) Sekantong Luka Dari Seorang Ibu, (3) Bunda, Kirimkan Nanda Doa-Doa, (4) Jalan Pulang, (5) Alamat Maut, dan (6) Ibuku Tak Pernah Menangis. Penelitian ini berusaha mengungkapkan bagaimana sosok penyair dalam puisinya dengan harapan dalam prosesnya dapat menyentuh makna sajak-sajak puisi tersebut secara utuh.

Adapun puisi-puisi karya Irianto Ibrahim di atas, memiliki sisi tersembunyi yang dalam penafsirannya membutuhkan pembacaan secara berulang-ulang, untuk menemukan kemungkinankemungkinan yang terselubung. Disinilah "aku-lirik" akan terhubung sebagai suatu fenomena dalam teks yang dapat berarti membentuk sebuah simbol karena pengaruh metafora, baik dalam momen semantik dan momen nonsemantik. Momen semantik adalah hubungan makna literal dan makna figuratif dalam ungkapan metaforis sedangkan momen nonsemantik adalah peristiwa terjadinya simbol secara independen karena adanya peristiwa dan tidak ada bahasa yang mampu menguraikannya secara detail.

\subsection{Pembacaan Hermeneutik Sajak Buton 1969}

\section{Buton 1969}

Begitu tahun-tahun menjadi sepi
Dan malam bergegas menyibak riak waktu

Kau tak usah mendesak laut menyurut Atau pohon-pohon mengemis angin Karna darah lebih kental dari luka Lebih sakit dari kenangan

Mungkin kau butuh semacam nestapa Atau ruang khusus penampung berkarung sesal

Sambil bersiul menanti pisau waktu Yang berjubah hitam, persis nenek sihir

Bukan tawar-menawar yang kau tunggu

Karna gagak tak pernah lupa alamat malam

Dari matanya yang menikam kelam Meski berkali-kali kau menyebut ingin Ia tak hinggap di sana

Tidak di deretan kata yang mетиаt namamu

Pulanglah, kembali ke bilik langit

Sambil bersiul sepanjang luka

Sepanjang kenangan yang menghanguskan

Tahun-tahun cerita

Seperti ketika kau melewati tanah perbatasan

Tanah yang di jaga para tentara yang selalu marah

Adalah peta yang sama kau jejaki

Dari ujung nadi terjauh

Tempat anjing-anjing kurus

Dengan liur yang tak pernah kering

Mendesakmu dengan seribu tuduhan

Semacam gua yang ditolak para pertapa

Kau khusuk menulis nestapa

Darah lebih kental dari luka

Lebih sakit dari kenangan

Buton, 2007

Puisi ini jelas mengungkapkan makna akan sejarah Buton yang di tuduh sebagai basis Partai Komunis Indonesia (PKI) oleh pemerintahan 
NKRI saat itu. Hal ini jelas terlihat oleh penyair yang memberi judul puisinya “Buton 1969”. Tahun 1969 merupakan latar waktu terjadinya peristiwa bersejarah bagi masyarakat Buton tersebut. Pada tahun 1969, Buton dituduh sebagai basis PKI hanya karena sebuah informasi bahwa Buton menjadi tempat penyelundupan senjata dari Cina. Bupati Buton, Muh. Kasim beserta lebih kurang 40 orang aparat pemerintah Buton dan anggota ABRI asal Buton ditangkap tanpa surat perintah. Rumah-rumah penduduk digeledah dan banyak harta mereka dirampas. Buton banjir darah 4 tahun setelah G30S PKI. Padahal setelah dilakukan penyelidikan ternyata di Buton tidak ditemukan senjata dan tidak ditemukan ada operasi pemasokan senjata dari Cina. Yusran Darmawan dalam bukunya Menyibak Kabut di Keraton Buton (Respect, 2008) juga menegaskan bahwa isu Buton sebagai basis PKI direspon oleh pihak militer yang langsung melakukan penangkapan pada ratusan orang Buton. Selain itu juga, Saleh Hanan, penulis buku Catatan Jurnalis Operasi Militer 1969: 'Buton Basis PKI' (2000) mengungkapkan bahwa isu tersebut digulirkan untuk melemahkan dan sekaligus mematikan putra-putra terbaik Buton. Sajak ini sungguh mengurai tragedi dan sejarah yang kelam di Buton tahun 1969.

Sajak di atas secara spritual menunjukan hakekat manusia sebagai makhluk yang terbatas, yang tidak akan lepas dari kematian. Seperti dalam kalimat "bukan tawar-menawar yang kau tunggu, karena gagak tak pernah lupa alamat malam" yang digunakan sebagai simbol kematian yang terdapat pada puisi tersebut.

\subsection{Humanisme dalam Puisi Buton 1969}

Menurut Montaigne (Suwardi, 2012:130) dibutuhkan interpretasi ekstra untuk memahami sesuatu (sastra). Interpretasi sering kali hadir dari subjek. Subjek (peneliti) ikut masuk dalam penafsiran. Oleh karena itu hampir seluruh makna karya sastra berasal dari rangkaian subjek-subjek yang dimodifikasi. Sajak-sajak dalam puisi Irianto Ibrahim dalam sudut pandang penafsairannya adalah rangkaian-rangkaian yang utuh sebagai aktifitas penafsiran. Salah satunya dalah sajak Buton 1969 yang merupakan manifestasi jiwa spritual dan sejarah Buton yang di ketahui Irianto Ibrahim. Seperti yang telah dikemukakan sebelumnya bahwa yang menjadi pokok pembicaraan dari puisi Buton 1969 tersebut adalah kematian sebagai kuasa Tuhan yang Maha Esa. Mengemukakakan pada sajak "Buton 1969”, penyair justru tampak keluhuran kerohaniaanya yang berdiri menanti pisau waktu sambil bersiul sepanjang luka. Telah menjadi rahasia umum bahwa sebagai aktifitas kreatif, puisi sejalan dengan genre sastra lainnya: novel, cerpen, dan drama pada dasarnya merupakan cerminan perasaan, pengalaman dan pemikiran penyairnya. Dengan demikian keadaan serta gambaran kiehidupan masyarakat seperti telah dialami, ditangkap, direka, ditafsirkan, dinilai, atau diimajinasikan oleh penyairnya, sering dapat diketahui lewat puisi.

Terdapat tiga wilayah penting kehidupan manusia yang selalu ditimba oleh para penyair sebagai sumber penciptaan puisi-puisinya (Suminto, 2008:39). Pertama dan utama adalah wilayah kehidupan individual, kedua kehidupan sosial, dan ketiga kehidupan agama. Dengan 
kata lain puisi akan selalu berkenaan dengan masalah manusia dalam hubungannya dengan diri sendiri, dalam hubungannya dengan manusia lain, dan dalam hubungannya dengan Tuhan.

Memahami humanisme dalam puisi yang berjudul "Buton 1969" dapat dijumpai melalui ekspresi yang muncul disetiap kata-kata yang ditempatkannya. Sejenak ketika membaca puisi tersebut pembaca akan dibawa ke dalam suasana yang bisu dan hening. Akan tetapi dibalik kebersahajaan itu didapatkan satu gagasan yang bersifat filosofis. Melalui penghayatan yang intensif, pembaca akan merasa adanya tanggapan penulis yang bersifat fakta sejarah. Fakta di tempatkan sebagai elemen penting pada puisi tersebut. Hal itu terjadi karena lubuk hati dan perasaan pembaca adalah sasaran yang ingin dicapai dengan kata-kata puisi, dengan sarana yang mengedepankan fungsi konotatifnya.

Dengan demikian maka diketahui bahwa humanisme yang terdapat dalam puisi Buton 1969 yakni eksistensi manusia sebagai maklukh spiritual dan berkesinambungan dengan maksud penulis yang menyatakan sikap toleransi antar manusia sebagai aktifitas dan interaksi sosial.

\subsection{Pembacaan Hermeneutik Puisi Sekantong Luka Dari Seorang Ibu}

\section{Sekantong Luka Dari Seorang Ibu}

:kepada ibu ainun kasim

Supaya dapat kau ceritakan pada mereka perihal dada yang terhimpit ini:

Dada seorang ibu yang tak sempat melihatmu menangis atau sekedar tersedu. Sebab baginya kaki-kaki kursi yang diinjakkan pada kuku-kuku kaki suaminya tak pernah benarbenar mengenal rasa sakit: oleh luka maupun oleh kepergian yang dipaksakan. Ia ingin mengutuki dirinya jadi batu atau serumpun pohonan bambu tempat putri tanah ini terlahir. Ia ingin menjadi jembatan, tempat anak-anaknya menyebrangi cita-cita tanpa tangan kekar sang ayah, namun suara tertahan dari leher tercekik tak sempat memandunya berdoa.

Di sebelah sana: di ujung pantai terjauh, ia melihat kapal-kapal mengibarkan layar dan memasang lampu-lampu. Ia ingat putrinya yang minta kapal-kapalan. Ia rabai riak selat yang tak sempat jadi gelombang: ia urungkan senyumnya. Dadanya sesak. Dada seorang ibu yang tak sanggup memberi: dada seorang ibu yang menyuruh anak-anaknya mengatup bibir mereka sebelum tersenyum. Dada yang menanmpung sunyi nyanyian mantra para tetua adat.

Di punggungnya, ribuan tanda Tanya dipikulkan anak-anaknya. Tanya yang melarangnya berbaring. Tanya yang dijawab dengan tatapan mata berkilat-kilat. Semacam perisai para tentara yang di sarungkan pada tangan sebelah kiri, ia menutup mukanya. Ia sembunyi dari desakan yang menghimpit. Nafasnya tersengal, isaknya sesegukan. Lalu dibasuhnya muka merahnya dengan darah suaminya. Darah yang dicecerkan dua belas kendi jampi-jampi. Darah dari lipatan perih dan air mata yang sekarang menyerah. Darah yang dikemudian hari akan ia larung ke laut banda. Laut yang akan menenggelamkan suaranya.

Bahkan mungkin, bila kau betah menyibak perih: mendefenisikan 
penistaan. Ia seorang ibu yang tak dibolehkan mengucap tahlil saat pemakaman suaminya. Yang meronta dan menangis sambil mengintip dari kangkangan kaki kekar penggali kubur tanpa rasa iba di wajah mereka. Ia bicara pada tanah yang tak bisa mendengar suaranya sendiri. Ia inginkan pelukan seorang suami. Pelukan terakhir yang ingin ia bingkai dengan pelepah pisang atau patahan ranting pohon jarak dari kuburan itu. Ia, seorang ibu yang hanya memiliki sebatang pensil atau sketsa keluarga, dengan wajah sang suami yang sengaja akan disamarkan. Satu hari nanti, bila mungkin kau bias bercerita pada seorang lain, jangan bilang ia tak sempat meneteskan embun untuk bunga-bunga di halaman rumahnya. Sebab seusai sholat subuh, saat para nelayan telah kembali ke dada istri-istri mereka, ia masih khusuk menciumi sebekan kafan yang tak sempat ia balut pada tubuh suaminya.

Kendari, 2009

Puisi ini merupakan salah satu puisi yang menggambarkan sosok si penyair yang gemar menggunakan kata-kata yang ringan dengan makna kalimat yang mendalam. Salah satu dari sekian puisinya yang bersifat narasi dan berlatar belakang sejarah. Puisi ini di dedikasikan kepada ibu Ainun Kasim, istri Bupati Boton saat itu, Muh. Kasim.

Pada dasarnya puisi "Sekantong Luka Dari Seorang Ibu" secara keseluruhan bermula pada kehidupan pengandaian sosok si $I b u$, ketika waktu yang diandaikan tiba maka si Ibu menginginkan "supaya dapat kau ceritakan pada mereka perihal dada yang terhimpit ini". Si Ibu kemudian dengan lembut menceritakan duka laranya kepada anak-anaknya yang diinginkanya dapat "menyebrangi cita-cita tanpa tangan kekar sang Ayah". "ia urungkan senyumnya, dadanya sesak" karena ia adalah seorang Ibu yang tak sanggup memberi. Ia ibu yang "memikul ribuan tanda tanya" di punggungnya, sebab suaminya telah mati kemudian "dibasuhnya muka merahnya dengan darah suaminya", sebuah tanda bahwa ia telah "menyerah". Ia merupakan seorang $I b u$ yang tak sempat memakamkan suaminya dengan semestinya "tak dibolehkan mengucap tahlil saat pemakaman suaminya".Ia teramat sangat merindukan "pelukan seorang suami", seperti saat subuh, seperti nelayan-nelayan yang pulang pada istri-istrinya. Namun yang terjadi saat itu adalah "ia masih khusyu menciumi sobekan kafan yang tak sempat ia balutkan pada tubuh suaminya".

Dalam menafsirkan puisi, satu hal yang penting adalah puisi itu sendiri. Dengan kata lain sajak "Sekantong Luka Dari Seorang Ibu" karya Irianto Ibrahim ini akan diposisikan menuju teks yang utuh, walau pada kenyataannya dan tidak asing lagi bahwa Irianto Ibrahim itu sendiri adalah pencipta sajaknya, sehingga dengan membaca kata "aku" dalam sajak tersebut bisa saja terbayang sosok penulis. Namun pikiran tersebut untuk sementara akan dihilangkan. Ketika membaca sajak ini, dalam tindakan pemaknaannya akan menuju total sebagai ibu Ainun Kasim sebagai seorang yang tertuju. Sehingga "aku-lirik"dalam sajak menjadi milik pembaca agar seolaholah pembaca akan turut dalam merasakan peristiwa, memperoleh pengetahuan, dan menyelami makna yang terkandung didalamnya. Seperti halnya yang diungkapkan oleh Paul 
Ricoeur (prastiono dkk, 2010:225) yang mengatakan bahwa teks adalah diskursus yang dibakukan lewat tulisan.

Dalam puisi "Sekantong Luka dari Seorang Ibu" karya Irianto Ibrahim ini pada dasarnya membahas tentang sisi individualistik yang dimliki oleh sosok si "Ia-Ainun Kasim-Ibu". Dapat terlihat dari kalimat di bawah judul puisi yang mengungkapkan bahwa penulis puisi "Sekantong Luka dari Seorang Ibu'bermaksud mendedikasikan karyanya kepada Ibu Ainun Kasim yang notabene menjadi sosok dan tokoh utama dalam puisi.

Gambaran tentang sosok si "ibu" mengenai individu yang di gambarkan oleh penyair mengacu terhadap sikap keibuan yang ia miliki. Dapat terlihat dalam bait pertama baris "ia ingin menjadi jembatan, tempat anak-anaknya menyebrangi cita-cita tanpa tangan kekar sang ayah". Ini menjelaskan bahwa ia akan menjadi seorang diri menghidupi anak-anaknya, mendorong tercapainya cita-cita dan mimpi anak-anaknya, dan mengganti seluruh peran ayah bagi anak-anaknya yang telah atau akan tiada entah karena suatu hal. Hal ini sejalan dengan hakekat manusia sebagai individu yang berdiri sendiri dan pola berpikirlah sebagai tanda keindividualan sehingga dalam diri akan tercipta hasrat dan keinginan.

\subsection{Humanisme dalam Puisi \\ Sekantong Luka dari Seorang \\ Ibu}

Pemahaman tentang identitas diri sebagai suatu individu yang terkekang oleh keadaan akan dirinya sendiri, sepertinya hal ini yang mendorong Irianto Ibrahim untuk menghasilkan sajak "Sekantong Luka Dari Seorang Ibu". Telah dijelaskan sebelumnya, secara objektif pemaknaan sajak "Sekantong Luka Dari Seorang Ibu" terlebih dahulu si Ibu merupakan lirik yang artinya pemakanaan tentang sosok Ainun Kasim akan utuh jika si Ibu dipandang memilik relasi makna dengan keseluruhan sajak. Dalam hal ini pemaknaan tentang si $I b u$ terkait dengan keseluruhan teks (sajak sebagai teks yang siap diinterpretasikan). Oleh karena itu sebaiknya menginterpretasikan teks puisi haruslah dipandang sebagai sesuatu yang otonom dan memiliki relasi antar unsur-unsur yang membentuknya menjadi sebuah sajak puisi sehingga dalam pemaknaanya , makna akan didapat secara utuh melalui proses interpretasi. Adapun keterlibatan pengarang pula menjadi sarana yang yang vital dalam pengukuhan makna karena puisi merupakan media ekspresi pengarang. Jadi, untuk mencari makna teks pusi secara utuh terlebih dahulu mampu memahami hubungan antara pembaca sebagi penafsir dan sajak sebagai media ekspresi dari sudut pandang pengarang (teks).

Puisi "Sekantong Luka dari Seorang Ibu" karya Irianto Ibrahim membawa pembaca pada perenungan diri yang bersifat intrapersonal. Dari sudut pandang penulis puisi kita dapat memahami bahwa sosok "ibu" merupakan tokoh yang sengaja dipilih penulis untuk menunjukan sisi yang lebih dalam yang terdapat dalam diri manusia. Sisi itu dapat berupa alam internal manusia itu sendiri serperti pikiran, hasrat, naluri, ego, takdir dan lain sebaginya. Dari hal tersebut maka akan menghsilkan sebuah pertanyaan yang merujuk pada siapa si ibu? Untuk menjawab pertanyaan tersebut maka perlu memahami relasi antara 
pembaca sebagi pihak yang menginterpretasikan sajak, puisi sebagi sebuah teks yang mengandung fakta sejarah, dan pengarang yang melahirkan sajak sebagi tindakan ekspresinya terhadap lingkungan yang ia pahami. Seperti kata jakobson yang mengikuti pendapat segers mengenai fungdi puitik (Kaelan, 2009:210), fungsi puitik didefenisikan sebagai seperangkat yang mengarah kepada pesan yang terpusat atau dikatakan juga merupakan fungsi dari ekspresi pemikiran bahasa puitik. Sedangkan fungsi emotif atau fungsi ekspresif yang berfokus pada pengirim, menurut jakobson (Kaelan, 2009:210) menunjukkan ekspresi langsung dari sikap pembicara terhadap apa yang dibicarakan. Oleh karena itu pengarang, puisi, dan pembaca adalah satu kesatuan yang utuh ketika akan memahami makna sajak secara keseluruhan. Maka rujukan sosok si $i b u$ akan terlihat ketika hendak menafsirkan sejak secara keseluruhan.

Pelanggaran hak asasi manusia ini di ibaratkan oleh penulis sebagai suatu kerugian bagi pihak korban. Manusia sejatinya adalah mahluk yang menginginkan kebebasan, adapun kebebasan itu sendiri dapat berupa pengertian terbebas dari kungkungan diri yakni kesadaranya sebagai individu yang berpikir dan kebebasan berupa terbebas dari permasalahan-permasalahan sosial yang ada dalam tradisi masyarakat pada masa itu.

Maka dapat ditarik kesimpulan bahwa puisi Sekantong Luka dari Seorang Ibu mendalami sikap manusia sebagai maklukh yang tak lepas lepas dari interaksi sosial sebagai aktifitas lingkungan serta manusia sebagai makhluk spiritual.

\subsection{Pembacaan Hermeneutika Puisi Bunda, Kirimkan Nanda Doa- Doa}

\author{
Bunda, Kirimkan Nanda Doa-Doa \\ Bunda, kirimkan nanda doa-doa \\ Hari hampir senja \\ Pekat akan menelanku
}

Bunda,

Senja hari aku mengeja namamu Sampai embun meninggalkan daun Aku hirup lagi setia dari susumu Dari lenganmu

Bunda,

Kirimkan nanda doa-doa

Beserta bau tubuhmu

Buton, 2000

Apa yang hendak ditujukan penyair melalui gambaran puisi "Bunda, Kirimkan NandaDoa-Doa" melalui kata-kata pilihan yang digunakan menunjukan sisi keharuan hubungan antara seorang anak dan ibunya. Perulangan pernyataan Bunda, kirimkan nanda doa-doahingga akhirnya dapat kita maknai kesungguhan permohanan dari seorang anak yang jauh daribunda. Kemudian tibalah pada titik pernyataan yang seolah mengatakan keputus asaan yang tengah dihadapi oleh seorang anak, hari hampir senja, pekat akan menelanku. Akibatnya pembaca seolah mendapat atau membayangkan betapa kuat hubungan antara kedua tokoh dalam puisi ini dalam baris Aku hirup lagi setia dari susumu, dari lenganmu.

Penyair kembali melibatkan diri yang nampak sekali terlihat dalam sajaknya yakni pemilihan kata nanda yang digunakan oleh penyair. Kata Nanda akan mewakili diri sebagai seorang penyair, kemudian akan diakui oleh pembaca sebagai wujud dirinya sendiri untuk menemukan 
makna puisi.. Dalam wujud si nanda penyair merasakan hari hampir senja, pekat akan menelanku. Kata senjamemiliki arti yang merujuk ke kegelapan yang memiliki makna bahwa si nanda akan tertelan oleh kegelapan, dalam hal ini penyair menunjukan keputus asaan oleh sesuatu.

Pada bait terakhir puisi sekilas mengulang kembali baris pertama dalam puisi tersebut. Ini mengindikasikan peyair berusaha mempertegas makna kerinduan dengan menambahkan kalimat beserta bau tubuhmu. Demikian dapat kita maknai sebagai seorang anak yang teramat sangat merindukan bundanya yang berada jauh darinya.

\subsection{Humanisme dalam Puisi Bunda, Kirimkan Nanda Doa-Doa}

Memahami makna puisi Bunda, Kirimkan Nanda Doa-Doa di atas, secara garis besar kita dapat menarik benang merah perasaan seorang anak yang oleh penyair di gambarkan dengan sosok nanda kepada sosok bunda.

Dalam puisi "Bunda, Kirimkan Nanda Doa-Doa" karya penyair Irianto Ibrahim ini pada dasarnya membahas tentang sisi individualistik yang dimliki oleh si nanda. Dapat terlihat dari judul sajak ini yakni menggunakan kata "Nanda" yang memiliki pengertian sebuah kata ganti orang pertama tunggal atau sering pula disebut pronomina pertama tunggal. Pengertian tersebut mengindikasikan makna kata aku menuunjuk pada gambaran karakter individu atau unsur ego yang terdapat dalam diri sosok si nanda ini. Oleh karena itu untuk memudahkan penangkapan makan sajak, penafsiran sajak ini akan diawali pada sebuah pernyataan yang tegas melalui baris "bunda, kirimkan nanda doa-doa". Baris ini merupakan pengibaratan sosok si nanda secara tegas menyatakan bahwa dirinya adalah seseorang yang sedang menuntut sesuatu dari bunda. Oleh karena itu baris ini amat menarik karena si aku menganggap bahwa dirinya adalahseorang yang mebutuhkan sesuatu yaitu doa-doa. Kata "doadoa" teramat dekat artinya dengan sebuah harapan. Karena membutuhkan harapan, sosok si nanda berarti telah kehilangan harapan di tempatnya berada yang jauh dari sosok si bunda. Berdasarkan penjelasan tersebut maka dapat diperoleh gamabaran mengenai sosok si nanda ini. Saosok si nandadalam baris tersebu akan menuju titik acuansi aku sebagai sebuah individu yang sendiri namun membutuhkan pertolongan dari manusia lainnya. Hal ini sejalan dengan hakekat manusia sebagai individu yang membutuhkan orang lainnya untuk berdiri dengan pola berpikir sebagai tanda keindividualan sehingga dalam diri akan tercipta hasrat dan keinginan.

Pada baris selanjutnya, yang diinginkan oleh si nanda ketika tibalah masanya adalah harapan atau rasa simpati dari si bunda. Masa yang dimaksud yakni merujuk pada baris hari hampir senja, pekat akan menelanku. Memilihat sosok bunda dalam baris ini, menunjuk pada sosok yang memberi memberiharapandan sosok yang si $a k u$.Baris kedua dan ke tiga puisi ini menunjukan bahwa telah habis harapan jika pekat telah menelannya. Berdasarkan penjelasanpenjelasan tersebut maka sosok bunda akan tergambar sebagaisosok yang diharapkan dapat menolong si nanda.

Dengan demikian dapat di ambil kesimpulan bahwa sosok nanda adalah 
seorang individu yang membutuhkan orang lain untuk menjalani kehidupannya. Puisi "Bunda, Kirimkan Nanda Doa-Doa" karya Irianto Ibrahim membawa pembaca pada perenungan diri yang bersifat intrapersonal, jadi kita dapat memahami bahwa kata "nanda" merupakan diksi yang sengaja dipilih penyair untuk menunjukan sisi yang lebih dalam yang terdapat dalam diri manusia yang membutuhkan orang lain. Sisi itu dapat berupa alam internal manusia itu sendiri serperti pikiran, hasrat, naluri, ego, dan lain sebaginya.

\subsection{Pembacaan Hermeneutika Jalan Pulang}

\section{Jalan Pulang}

Mungkin aku butuh semacam kantong ajaib

Yang membuatku tiba-tiba menjadi sajak

Yang tidak pernah sungguh-sungguh mencintai

Sampai baris terakhir

Atau aku butuh semacam topi pesulap Yang membuatku lenyap seketika Kepergian yang tak pernah kembali Yang tak akan pernah datang lagi

Mungkin masih ada jejak senyum Atau malam bisu di ranjang

Karna alamat hari masih tersimpan di saku bajuku

Di dada sebelah kiri

Tempat jantungku biasa memanggilmu

Aku tidak bicara pada kenangan

Pada laut yang menjelma ombak dalam dirimu

Atau lagu terakhir yang dinyanyikan para pemabuk

Sudah lama tak kupikirkan rimbun mawar
Atau kabut asap sepanjang penantian Sebab kenangan bukan jalan pulang untuk kembali

Bukan isyarat hari yang mau berbagi Kendari, 2007

Puisi Jalan Pulang merupakan sajak yang berbicara mengenai suatu kecemasan yang didapatkan oleh si penyair dalam pergulatannya menciptakan karya. Sebagai manusia yang pada hakekatnya memiliki akal dan pengalaman serta wawasan dalam memahami lingkungannya, si penyair sadar akan kualitas dirinya dalam rangka memproduksi karya cipta melalui sajak-sajak.

Bagi setiap penyair, kata-kata merupakan sesuatu yang bukan hanya terbaca sebagai bentuk yang sistematis dalam konteks verbalnya, namun katakata juga amat peranannya dalam menunjang makna sajak secara utuh. Lihat saja pada bait ini, si penyair dalam sajak ini membuat seakan katakata adalah hal yang menunjang pencapaiannya ke arah kebebasannya dalam berkarya. Bagi si penyair, jika kata-kata dihabiskannya maka dia sendiri merasa terbatasi langkahnya bahkan dia sendiri pun merasa bahwa dengan "tiba-tiba menjadi sajak" ia "tidak pernah sungguh-sungguh mencintai". Hal ini mengindikasikan bagaimana sajak dalam perspektif, jika kata digunakan sebagai pembentuk sajak maka kata bagi si penyair adalah sesuatu yang tidak akan mengekang dirinya sehingga ia bias terbebas dari sesuatu yang seharusnya. Pada akhirnya dapat diketahui bahwa seorang penyair memang seorang yang berbicara kepada khalayak lewat sajak. Jadi, puisi merupakan sarana pilihan penyair dalam membangun komunikasi dengan audiensnya. Seperti dalam bahasa Rendra kutipan

48 | Jurnal BASTRA (Bahasa dan Sastra), Vol. 4 No.1, Edisi Januari 2019/e-ISSN: 2503-3875/ http://ojs.uho.ac.id/index.php/BASTRA 
sajaknya yang berjudul Surat Cinta, secara ringkas dikatakan bahwa penyair adalah "orang yang bermula dari kata", yakni "kata yang bermula dari kehidupan pikir dan rasa."

Betapa penting kata bagi seorang penyair sebab kata adalah inspirasi ekspresi untuk menyampaikan maksud serta tujuaannya terhadap kondisi-kondisi yang dipahami penyair dalam kehidupan. Bait pertama yang ditulis oleh penyair pada kutipan "mungkin aku butuh semacam kantong ajaib, yang membuatku tiba-tiba menjadi sajak" adalah penjelasan yang masih terkait dengan kecemasan si penyair. Keresahan dan kecemasan ketika berada dalam keadaan dimana ia menjadi sesuatu yang terbatas, seperti yang dituangkan dalam bait ke dua juga, yaitu "atau aku butuh semacam topi pesulap, yang membuatku lenyap seketika". Hal ini mengindikasikan bahwa penyair menginginkan sesuatu yang bersifat bebas yakni "kepergian yang tak pernah kembali, yang tak pernah datang lagi".

Kedalaman pemikiran si penyair mengenai sajak, membawanya pada suatu kesadaran untuk menganggap bahwa kata sebagai faktor penting yang menunjang pembentukan sajak. Olehnya itu ia pun mengungkap bahwa sebab kenangan bukan jalan pulang untuk kembali, bukan isyarat hari yang mau berbagi tidak lain karena kenangan bukanlah sesuatu yang bertahan lama jika posisi kata masih dianggap dalam pemahaman kebendaan.

Dengan demikian, makna puisi Jalan Pulang dapat mengimplementasikan kodrat manusia sebagai makhluk yang akan selalu berhubungan dengan manusia lainnya sebagai bentuk interaksi sosial dalam kehidupan.

\subsection{Humanisme dalam Puisi Jalan Pulang}

Puisi, seberapa pun kentalnya bahasa yang digunakan, memiliki pengetahuan yang dipahami sebagai wacana. Dalam hal ini, puisi merupakan ekspresi puitik seorang penyair yang mengandung nilai-nilai kemanusiaan. Pada wilayah ini ada simbol terselubung yang tidak dapat dipahami oleh orang pada umumnya karena bersifat sangat individual.

Puisi sebagai sosok pribadi penyair atau ekspresi personal berarti puisi merupakan luapan perasaan atau sebagai produk imajinasi penyair yang beroperasi pada presepsi-presepsinya. Dalam hubungan ini, aspek yang bersifat emosional lebih menonjol daripada yang intelektual. Itulah sebabnya tidak mengherankan jika puisi sering juga disebut sebagai bahasa perasaan. Artinya, bahasa yakni kata-kata dalam puisi sebagai sosok pribadi penyair lebih difungsikan untuk menggambarkan, membentuk, dan mengekspresikan gagasan, perasaan, pandangan, dan sikap penyairnya. Oleh karena itu, tidak mustahil dibelakang atau lebih tepat di dalam puisi berdiri pribadi penyairnya lengkap dengan pengalaman-pengalaman yang diperoleh penyair dalam kesehariannya. Berhadapan dengan puisi, dengan demikian, pembaca sebenarnya sedang membangun tegur sapa dengan penyairnya.

Puisi Jalan Pulang seperti yang telah diungkapkan di atas, bahwa sajak tersebut pada dasarnya mengungkap sisi kecemasan penyair. Kehidupan yang menceritakan kecemasan merupakan sebuah 
kehidupan yang mengarah pada kematangan diri manusia.

\subsection{Pembacaan Hermeneutik Alamat Maut}

\section{Alamat Maut}

Kaupun tak akan melihat pantai itu dari jendela

Meski dengan bibir bergetar

Dengan mata nanar

Terlalu singkat sebagai derita

Namun, teramat panjang sebagai duka

Ada nada pilu tersendat

Dasar laut yang menandai maut

Dan lambaian penghabisan yang luput dari ingatan

Lebih dalam dari segala alasan

Kata yang tak dapat dipadankan dengan kelam

Dengan seribu malam yang mendekam

Atau deras arus yang mengancam

Pilu yang dalam dan suram

Kau hanya dapat menabur bunga dari jendela

Dan ombak akan terus menuju pantai

Sementara di langit

Awan kelabu bukan miliknya lagi

Buton, 2007

Dalam puisi "Alamat Maut" karya Iryanto Ibrahim ini secara tidak langsung yang menjadi orang pertama tunggal atau "si aku" adalah penyair sendiri. Kita dapat lihat dibaris pertama ada kata "kau" berarti disini secara tidak langsung penyair yang berbicara, olehnya orang pertama dalam puisi ini adalah penyair sendiri. Tetapi tidak ditunjukan langsung didalam cerita puisinya. Dalam puisi ini merupakan tokoh protagonis yaitu tokoh yang membawakan peristiwa atau menyampaikan sesuatu kepada pembaca.
Dalam puisi "Alamat Maut" karya Iryanto Ibrahim menggunakan gaya bahasa atau majas asonasi. Asonasi adalah sejenis bahasa refetisi yang berjudul pengulangan vokal, pada suatu kata atau beberapa kata, biasanya dipergunakan dalam puisi untuk mendapatkan efek penekanan. Kita dapat lihat pada bait pertama dalam puisi ini terdapat unsur-unsur penekanan bahwa penyair memberikan kita gambaran. Lihatlah pada bait pertama begitupun pada bait-bait berikutnya

kau tidak akan dapat melihat pantai itu dari jendela

meski dengan bibir bergetar

terlalu singkat sebagai derita

namun teramat panjang sebagai duka

Bait ini menggambarkan ada sesuatu yang yang terlalu singkat sebagai derita namun, teramat panjang sebagai duka, yakni kematian. Meskipun dengan mata yang nanar dengan bibibr bergetar dan segala upaya yang dilakukan kita tak akan mampu melihatpantai dari jendela. Penyair menggambarkan pantai dari jendela sebagai upaya mempertahankan dunia.

Sajak di atas secara spritual menunjukan hakekat manusia sebagai makhluk yang terbatas, yang tidak akan lepas dari kematian. Seperti dalam kata Alamat Maut yang digunakan sebagai simbol kematian yang terdapat pada judul puisi tersebut. Maut adalah sebuah kata yang digunakan sebagi penanda kematian. Pada bait dalam puisi tersabut penyair memperingatkan secara sadar bahwa kematian bukanlah hal dapat dihindari atau sesuatu yang luput dari ingatan. Namun ada hal yang lebih penting dari melepas kepergian seseorang yang telah meninngal dunia yaitu

50 | Jurnal BASTRA (Bahasa dan Sastra), Vol. 4 No.1, Edisi Januari 2019/e-ISSN: 2503-3875/ http://ojs.uho.ac.id/index.php/BASTRA 
sebuah keikhlasan untuk menerima sesuatu yang telah pergi atau yang akan ditinggalkan.

\subsection{Humanisme dalam Alamat Maut}

Dibutuhkan interpretasi ekstra untuk memahami sesuatu (sastra). Interpretasi seringkali hadir dari subjek. Subjek (peneliti) ikut masuk dalam penafsiran. Oleh karena itu hampir seluruh makna karya sastra berasal dari rangkaian subjbjek-subjek yang dimodifikasi (Montaigne dalam Suwardi, 2012:130).

Puisi-puisi Irianto Ibrahim dalam sudut pandang penafsairannya adalah rangkaian-rangkaian yang utuh sebagai aktifitas penafsiran. Salah satunya dalah puisi Alamat Maut yang merupakan manifestasi jiwa spritual penyair. Seperti yang telahdi kemukakan sebelumnya bahwa yang menjadi pokok pembicaraan dari sajak Alamat Maut tersebut adalah kematian sebagai kuasa Tuhan yang Maha Esa yang harus diterima dengan iklas hati oleh manusia.

Sosok penyair dalam puisi Alamat Maut ini terlihat sebagai sosok yang telah pasrah tanpa ada keresahan, kegelisahan, yang mencerminkan jiwa yang sudah disapuh oleh penglihatan hidup. Mengemukakakan pada sajak "Alamat Maut", justru tampak keluhuran kerohanian penyair yang merasa kematian merupakan hal yang terlalu singkat sebagai derita namun teramat panjang sebagai duka. Telah menjadi rahasia umum bahwa sebagai aktifitas kreatif, puisi sjalan dengan genre satra lainnya: novel, cerpen, dan drama pada dasarnya merupakan cerminan perasaan, pengalaman dan pemikiran penyairnya. Dengan demikian keadaan serta gambaran kiehidupan masyarakat seperti telah dialami, ditangkap, direka, ditafsirkan, dinilai, atau diimajinasikan oleh penyairnya, sering dapat diketahui lewat puisi.

Kecendrungan sisi kemanusiaan dalam puisi Alamat Maut ini merupakan pergolakan ekspresi yang berpangkal pada pengalamanpengalaman dan pandangan hidup penyair terhadap alam sekitarnya. puisi Alamat Maut tersebut berkecenderungan memiliki unsur tematik dengan berpangkal pada jiwa spritualnya yakni yang percaya dengan kematian.

Dalam kebisuan puisi tersebut sampai kepada pembacanya, atau paling tidak mampu membangkitkan tanggapan secara asosiatif, padahal pembaca boleh jadi belum mengetahui secara pasti apa yang dimaksud oleh penyairnya. Puisi Irianto Ibrahim bertolak pada pengalaman jiwa yang luas dan lengkap sehingga mampu membangkitkan pengalaman pembaca sebelum dipahami secara keseluruhan. Pengalaman penyair dalam memperhatikan gejala-gejala alam seperti halnya kematian yang kemudian diterimanya sebagai kehendak Tuhan yang Maha memiliki kuasa menjadi bagian kehidupan yang harus dijalaninya. Melalui puisinya ia pun beranggapan hidup pasti akan selesai, berakhir secara cepat atau lambat. Hal itu pun ia sadari sebagai suatu kenyataan dan konsekuensi dibaili keradaan kehidupan manusia.

Sejalan dengan penjelasan yang sudai diuraikan di atas, maka kesimpulan yang dapat ditarik adalah makna puisi "Alamat Maut" karya Irianto Ibrahim sejalan dengan kodrat manusia sebagai makhluk yang takbisa lepas dari hubungan dengan tuhannya. 


\subsection{Pembacaan Hermeneutik Puisi Ibuku tak Pernah Menangis}

\author{
Ibuku Tak Pernah Menangis \\ Sejak ayah pergi \\ Malam-malam menjadi sama \\ Hari seolah berhenti di rumah kami \\ Sejak itu ibu tak pernah menangis \\ Tak ingin bicara
}

Kalau aku bertanya tentang jagung di ladang

Ibu hanya menatap

Kulihat dari matanya

Butir-butir jagung menyembul

Tumbuh, lalu kupetik di hatiku

Tapi hari masih berdiam di rumah kami

Masih belum pergi sejak ayah pergi

Ibu tak ingin bicara

Tak pernah menangis

Kendari, 2008

Inilah sosok Irianto Ibrahim yang menggambarkan kekuatan hati seorang ibu dalam menjalani kehidupan. Kisah hidupnya bersama sosok ibu ia ceritakan lewat puisi ini. Berbagai gambaran tentang ibu dan perjuangannya ditambah lagi dengan perjuangan seorang ibu dalam kehidupan keluarga. Mulai dari hubungannya dengan suami dan dalam memberikan segala yang terbaik bagi anak-anaknya. Sungguh penggambaran yang sangat menyentuh hati setiap pembaca. Hal ini dikarenakan penggunaan kata-kata dengan tidak mengabaikan landasan teori metafora, simbol dan konsep sehingga bait-baitnya terlihat memiliki banyak makna.

Seluruh baris saling sambung menyambung menjadi sebuah makna yang secara garis besar dapat di artikan sebagai sebuah kepiluan. Jagung dipilih oleh penyair sebagai sesuatu yang identik dengan lingkungan perkampungan, dimana jagung merupakan tanaman yang kerap dijadiakan komoditas utama masyarakat untuk bercocok tanam dan makanan pokok sehari-hari. Butirbutir jangung yang menyembul keluar dari mata ibu dapat di artikan sebagai air mata yang keluar karena sang anak bertanya tentang jagung di ladang, namun karena kepergian sang ayah/suami, jagung-jagung di ladang itu hanya tinggal menyisakan kepiluan. Selanjutnya olehair mata yang keluar dari sang ibu, member kekuatan yang baru untuk tumbuh didalam hati "lalu kupetik di hatiku".

\subsection{Humanisme dalam Puisi Ibuku Tak Pernah Menangis Puisi "Ibuku tak Pernah} Menangis" karya Irianto Ibrahim membawa pembaca pada perenungan diri yang bersifat intrapersonal. Dari sudut pandang penyair puisi kita dapat memahami bahwa sosok "ibu" merupakan tokoh yang sengaja dipilih penyair untuk menunjukan sisi yang lebih dalam yang terdapat dalam diri manusia. Sisi itu dapat berupa alam internal manusia itu sendiri serperti pikiran, hasrat, naluri, ego, takdir dan lain sebaginya.

Dengan kata lain, puisi ini merupakan sebuah perenungan diri bahwa pada hakikatnya, manusisa merupakan mahluk social yang hidupnya membutuhkan orang lain. Sosok ibu yang ditinggalkan oleh suaminya digambarkan penyair sebagai sosok yang menderita. Namun disisi lain, kehadiran sosok aku dalam puisi yang merupakan anaknya menjadi alasan tersendiri penyair memberi metafora sebagai pengkhiasan ketabahan sosok si ibu. Sosok ibu diharuskan menjadi orang yang tak pernah menangis.

Dalam perjalannanya, banyak pertanyaan tentang jagung diladang

52 | Jurnal BASTRA (Bahasa dan Sastra), Vol. 4 No.1, Edisi Januari 2019/e-ISSN: 2503-3875/ http://ojs.uho.ac.id/index.php/BASTRA 
merupakan sebuah contoh yang di berikan oleh penyair. Seperti yang telah dijelaskan sebelumnya, Jagung dipilih oleh penyair sebagai sesuatu yang identik dengan lingkungan perkampungan, dimana jagung merupakan tanaman yang kerap dijadiakan komoditas utama masyarakat untuk bercocok tanam dan makanan pokok sehari-hari. Butirbutir jangung yang menyembul keluar dari mata ibu dapat di artikan sebagai air mata yang keluar karena sang anak bertanya tentang jagung di ladang, namun karena kepergian sang ayah/suami, jagung-jagung di ladang itu hanya tinggal menyisakan kepiluan. Selanjutnya oleh air mata yang keluar dari sang ibu, memberi kekuatan yang baru untuk tumbuh didalam hati "lalu kupetik di hatiku”.

Secara keseluruhan dari puisi "Ibuku tak Pernah Menangis" ini berisi tentang ungkapan dari si "akulirik" bahwa kasih sayang seorang ibu begitu luar biasa. Ia harus menjadi sosok yang tegar walalupun harus menjalani kehidupan tanpa sosok ayah menjadi kepala keluarga. Maka dengan demikian, "puisi Ibuku tak Pernah Menangis" karya Irianto Ibrahim mendeskripsikan kodrat manusia dalam sikap toleransi antar manusia sebagai aktifitas dan interaksi sosial.

\section{PENUTUP}

\subsection{Kesimpulan}

Hasil peneletian pada enam puisi karya Irianto Ibrahim dalam kumpulan puisi Buton, Ibu dan Sekantong Luka dengan pembahasan mengenai, humanisme dalam puisi-puis Irianto Ibrahim menggunakan pendekatan ekspresif. Keenam puisi yang dimaksud adalah (1) Buton 1969, (2) Sekantong Luka dari Seorang Ibu, (3)
Bunda, Kirimkan Nanda Doa-Doa, (4) Jalan Pulang, (5) Alamat Maut, dan (6) Ibuku Tak Pernah Menangis. Pembicaraan berikut contoh-contoh analisis yang sudah dikemukakan di bagian terdahulu menunjukkan bahwa hakikat suatu karya yang disebut puisi itu dapat dilihat dari berbagai sisi, dan pengertian itu menjadi lebih lengkap jika dikaitkan dengan pengertian bahwa puisi merupakan sebuah pemahaman yang dibangun melalui teks. Seperti yang telah dikemukakan dalam pembahasan sebelumnya, berdasarkan analisis pada keenam karya Irianto Ibrahim itu sebagai karya kreatif penyair dapat mempertimbangkan bahwa sajak mesti mencakup ruang lingkup: (1) sebagai sosok pribadi penyairnya sendiri (pinjam istilah Subagyo Sastro Wardoyo), (2) sebagai dunia dalam kata (pinjam istilah Dresden), (3) sebagai penciptaan kembali atau refleksi kenyataan, dan (4) sebagai sesuatu yang dikehendaki untuk atau yang mampu mencapai tujuan tertentu dalam diri audiens.yang beroperasi pada presepsi-presepsinya.

Berdasarkan pembahasanpembahasan sebelumnya pula dapat terlihat konsep humanisme yang tertuang dalam puisi-puisi Irianto Ibrahim yang meliputi : (1) eksistensi manusia sebagai makhlukh spiritual (puisi Buton 1969, Bunda, Kirimkan Nanda Doa-Doa, dan Alamat Maut), (2) eksistensi manusia dalam sikap toleransi antar manusia sebagai aktifitas dan interaksi sosial (puisi Buton 1969 dan Sekantong Luka dari Seorang Ibu, Ibuku Tak Pernah Menangis dan Jalan Pulang), (3) manusia yang berhubung dengan sikap keindividualannya (puisi Bunda, Kirimkan Nanda Doa-Doa). 
Jika diamati secara seksama melalui contoh-contoh puisi yang telah dikemukakan di bagian sebelumnya, terdapat tiga wilayah penting kehidupan manusia yang selalu ditimba oleh para penyair sebagai sumber penciptaan puisipuisinya, yakni wilayah kehidupan individual, kehidupan sosial, dan kehidupan agama. Dengan kata lain, puisi akan selalu berkenaan dengan masalah manusia dalam hubungannya dengan diri sendiri, dalam hubungannya dengan manusia lain atau alam, dan dalam hubungannya dengan Tuhan.akan tetapi dalam kaitan ini, harus dicatat bahwa ketiga wialyah itu bisa saja secara simultan terungkapkan dalam puisi tertentu. Persoalannya, wilayah manakah yang menjadi focus perhatian penyair dan akahirnya dikedepankan dalam karyanya. Wilayah kehidupan sebagai sumber penciptaan puisi atau sebagai dasar ekspresi, terutama sekali bermula pada kehidupan individu penyair sebagai kreator.

Enam puisi ini memberi sebanyak-banyaknya pesan kepada pembaca dengan kesadaran bahwa puisi bukan sekedar sarana hiburan. Tapi lebih dari itu, puisi merupakan salah satu sarana edukasi. Maka pada dasarnya ke enam puisi ini berhasil memberikan banyak pelajaran dan manfaat kepada pembacanya.

\subsection{Saran}

Bardasarkan kesimpulan di atas, maka peneliti merasa perlu untuk menyarankn berbagai hal sebagai berikut:

1. Perlu diadakan penelitian lanjutan dengan kajian yang berbeda dari penelitian ini

2. Hasil tinjauan dan analisis makna terhadap konsep Humanisme dalam puisi dapat dijadikan sebagai bahan acuan bacaan yang berharga bagi peningkatan mutu kegiatan apresiasi puisi Indonesia modern pada umumnya dan puisi-puisi karya Irianto Ibrahim pada khususnya.

3. Agar menjadi salah satu bahan masukkan bagi sastrawan dalam menggarap mengenai analisis konsep humanisme dalam dunia apresiasi puisi.

\section{DAFTAR PUSTAKA}

Barthes, Roland. 2017. Elemenelemen Semiologi "Terjemahan M. Ardiansyah". Yogyakarta: BASABASI.

Damono, Sapardi Djoko. 2017. Bilang Begini, Maksudnya Begitu "Buku Apresiasi Puisi”. Jakarta: PT Gramedia Pustaka Utama.

Effendi, Anwar. 2008. Bahasa dan Sastra dalam Berbagai Perspektif. Yogyakarta: Tiara Wacana.

Endraswara, S. 2013. Teori Kritik Sastra. Yogyakarta: Centre Academic Publishing Service

Ibrahim, Irianto. 2010. Buton, Ibu dan Sekantong Luka. Yogyakarta: Framepublising.

Kosasih,E. 2012. Dasar-dasar Keterampilan Bersastra. Bandung: Yrama.

Kaelan. 2002. Filsafat Bahasa. Yogyakarta: Paradigma.

Megandika. 2015. Menafsir Dunia Sebuah Usaha Menyajikan Kembali Pemikiran George F. McLean dalam Rangka Merespon Zaman Global. Yogyakarta: Kanisius

Minderop, Albertine. 2013. Psikologi Sastra; Karya Sastra, Metode, Teori dan Contoh Kasus. 
Jakarta: Yayasan Pustaka Obor Indonesia

Mulyono, Edi. 2012. Belajar Hermeneutika Dari Konfigurasi Filosofi menuju Praksis Islamic Studies. Yogyakarta: IRCiSoD

Munir, Miftahul. 2005. Filsafat Kahlil Gibran: Humanisme Teistik. Yogyakarta: Paradigma.

Nurgiyantoro, Burhan. 2013. Teori Pengkajian Fiksi.Yogyakarta: Gajah Mada University

Press.

Richard, E. Palmer. 2016. Hermeunetika Teori Baru Mengenai Interpretasi. Yogyakarta: Pustaka Pelajar.

Pradopo, R. Djoko. 2007. PrinsipPrinsip Kritik Sastra. Yogyakarta: Gadjah Mada University Press.

Pradopo, R. Djoko. 2012. Beberapa Teori Sastra, Metode Praktik dan Penerapannya.

Yogyakarta: Pustaka Pelajar.

Ratna, Nyoman Kutha. 2008. Teori, Metode, dan Teknik Penelitian Sastra. Yogyakarta: Pustaka Pelajar.

Siswanto, Wahyudi. 2008.Pengantar Teori Sastra. Jakarta: $\mathrm{Pt}$ Grasindo.

Siswantoro. 2016. Metode Penelitian Sastra, Analisis Struktur Puisi. Yogyakarta: Pustaka Pelajar.

Teeuw, A. 2015. Sastra dan Ilmu Sastra. Bandung: Dunia Pustaka Jaya

Uniawati. 2006. Fungsi Mantra Melaut pada Masyarakat Suku Bajo di Sulawesi Tenggara. Kendari: Kantor Bahasa Provinsi Sulawesi Tenggara.

Wellek, Rene \& Warren, Austin. 2014. Teori kesusastraan. Jakarta: PT. Gramedia Pustaka Utama.
Wicaksono, Andri. 2013. Pengkajian Prosa Fiksi. Bandung: Penerbit Garudhawaca. 